\title{
Effects of Dried Distillers Grains with Solubles on Performance and Carcass Characteristics of Lamb
}

\author{
G. M. Abdelrahim ${ }^{1 *}$, J. Khatiwada ${ }^{2}$, and N. K. Gurung ${ }^{3}$
}

${ }^{1}$ Department of Food and Animal Sciences, Alabama A \& M University, Normal, AL 35762, USA; ${ }^{2}$ Department of Family and Consumer Sciences, A\&T State University, Greensboro, NC 27411 , USA; ${ }^{3}$ College of Agricultural, Environmental and Natural Sciences, Tuskegee University, Tuskegee, AL 36088, USA.

Received: June 14, 2012 / Accepted: May 18, 2014

\begin{abstract}
The effect of including two levels of dried distillers grains plus solubles (DDGS) in formulated diet on performance, and carcass characteristics of lambs was studied. Twentyfour Gulf Coast wether lambs $(46.1 \pm 1.2 \mathrm{~kg}$ initial BW, and 8 to 9 months of age) were divided into two groups based on their live body weight and randomly allocated to dietary treatments ( 2 per treatment; 4 lambs/pen; 8 lambs per treatment). Treatment diets containing DDGS at 0 (control), 12.7, or $\mathbf{2 5 . 4 \%}$ on a DM basis were fed lambs. Basal diet contained dry-rolled corn, soybean meal, and fescue/bermuda grass hay. Dry Distillers grains with solubles was added to the finishing diets at either $\mathbf{1 2 . 7}$ or $\mathbf{2 5 . 4 \%}$ of the dietary DM to replace corn and SBM in basal diet. The concentrate mixes containing DDGS were formulated to be isonitrogenous and isocaloric to meet the NRC requirements of lamb. After 135d feeding period final BW was recorded, then animals were slaughtered, and carcass parameters collected after a 48-h postmortem. Lamb performance and carcass quality data were analyzed using the GLM procedures. Dry matter intake and final BW of lambs were not different between treatment. Also, no differences were observed between treatments in hot and cold carcass wt, body wall fat, rib eye area, $12^{\text {th }}$ rib fat, and kidney and pelvic fat depots. However a significant decrease ( $P \leq 0.05)$ in average daily gain was found in lambs fed 0\% DDGS diet compared to those fed 12.7 and 25.4\% DDGS diets. These results supported the hypothesis that substitute of corn and SBM by up to $25.4 \%$ DDGS can be fed to lamb without adverse effect on carcass characteristics. Keywords: Distillers dried grains with solubles, lamb, growth.
\end{abstract}

*Corresponding author: gamal.abdrahim@aamu.edu

\section{Introduction}

Dry Distillers grains with solubles (DDGS) is the major coproduct of ethanol production from corn. It contains more than $30 \%$ crude protein with approximately $55 \%$ ruminally undegradable protein and $2.25 \mathrm{Mcal} / \mathrm{kg}$ net energy (Schingoethe ef al., 2009). However, it contains high fiber ( 46\% NDF) which negatively affects DDGS digestibility. The composition of DDGS is an ideal supplement for ruminants consuming low-to moderatequality forages (NRC, 2000; Stock et al., 2000; Spiehs et al., 2002; Archibeque et al., 2008; Jacob et al., 2008; Klopfenstein et al., 2008; Van Emon et al., 2008; Leupp et al., 2009; Koger et al., 2010). However, DDGS are relatively low in rumendegradable protein (DIP; $27.2 \%$ of $C P$ ) and relatively high in undegraded intake protein (UIP) (Archibeque et al., 2008; NRC, 2000). Hence, when DDGS are fed at levels of 6 to $15 \%$ of diet $D M$, their primary purpose is to serve as a protein source, and when fed at greater levels, DDGS become a source of energy (Klopfenstein, 2001).

The growth in the biofuel industries and subsequent development of dry-milling production facilities (Renewable Fuels Association, 2009; Gunn et al., 2010; Koger et al., 2010) resulted in volatile futures markets and increased grain costs traditionally used in feedlot diets (Gunn et al., 2010; Schmit et al., 2009). Consequently, to sustain profitability and thrive within their respective industries, livestock producers from all sectors began to seek ways to reduce feed costs, particularly the usage of byproducts such as DDGS, which can be used as a substitute for energy and protein sources in beef cattle diets (Stock et al., 2000, Archibeque et al., 2008; Klopfenstein et al., 2008; Vander et al., 2009; Gunn et al., 2010; Whitney and Lupton, 2010a).

Limited data is available on carcass characteristics of livestock fed DDGS (Depenbusch et al., 2008); and to our best 
knowledge, there is no current data available on carcass characteristics of lambs fed DDGS in general, and carcass characteristics when 25\% DDGS (DM basis) included in growing wether lambs diets in particular. Therefore, it was hypothesized that up to $25.4 \%$ DDGS inclusion would not have an adverse effect on the carcass of finishing lambs. The specific objective was to determine the influence of feeding DDGS on DMI, final BW, ADG, and carcass characteristics of meat sheep including hot and carcass weight, 12 th rib fat thickness, body wall fat thickness, kidney and pelvic fat depots, and rib muscle area.

\section{Material and Methods}

All animal care and handling procedures followed the farms' written guidelines set forth by FASS (1999) and all procedures involving animals were approved by the Animal Care and Use Committee of Alabama A\&M University (AAMU).

\section{Experimental Animals and Facilities}

The objective of this study was to evaluate the effects of feeding of three levels DDGS on growth performance and carcass characteristics of wether lambs. The study was conducted at AAMU Winfred Thomas Agricultural Research Station. A total of twenty-four Gulf Coast wether lambs $(46.1 \pm 1.2 \mathrm{~kg}$ initial BW; 7-8 months age) were randomly assigned to three experimental diets. Before initiation of this study, lambs were vaccinated for clostridial disease (Convexin 8, Schering-Plough, Kenilworth, NJ). During the trial, lambs were grouped and housed in pens (4 lambs/pen) equipped with plastic feeders and water buckets. Experimental diets were offered ad libitum once daily with free access to water. Feeders were checked daily and cleaned of contaminated feed (e.g., fecal contamination, wet feed caused by precipitation). Feed refusals were weighed, dried, analyzed for DM, and used to calculate DMl, and animal weights were recorded every $28 \mathrm{~d}$.

\section{Experimental Design and Treatments}

Lambs were grouped by weight and randomly allocated within blocks to three experimental diets. Treatments had two replicates of four lambs each ( $n=8 /$ dietary treatment). A basal diet containing dry-rolled corn, SBM, and hay was fed as the control diet (Table 1). Dry Distillers grains with solubles was added to the finishing weather diets at either 12.7 or $25.4 \%$ of the dietary DM to replace corn and soy bean meal (Table 1). The experimental diets were formulated to be isonitrogenous and isocaloric (on a NEg basis) and to meet or exceed the NRC (2007) requirements of a finishing lamb. Lambs were allowed 7-day adjustment period and 7-day transition period to the experimental diets followed by $135 \mathrm{~d}$ feeding period.

\section{Data Collection Procedures}

Initial and final body weights were the average of two body weights taken on consecutive days. After the 135-d feeding period, lambs were transported $(346 \mathrm{~km})$ to Auburn University
Table 1. Ingredient and chemical composition of different concentrates containing fescue/bermuda grass hay and varying levels of dried distillers's grains with solubles (DDGS) fed to finishing lambs'.

\begin{tabular}{|l|c|c|c|}
\hline \multirow{2}{*}{ Item } & \multicolumn{3}{|c|}{ Composition of treatment diets } \\
\cline { 2 - 4 } & \multicolumn{3}{|c|}{ Treatment diets, DDGS (\%) } \\
\cline { 2 - 4 } & O\% (control) & $12.7 \%$ & $\mathbf{2 5 . 4} \%$ \\
\hline Concentrate & \multicolumn{3}{|c|}{ Amount, \% } \\
\hline Fescue/Bermuda grass hay & 37.0 & 64.4 & 63.8 \\
\hline Total & 100 & 100 & 100 \\
\hline \multirow{2}{*}{ Concentrates ingredients, \% of DM } \\
\hline Cracked corn & 46.3 & 40.3 & 32.5 \\
\hline Soy Bean Meal (48\% CP) & 12.2 & 6.9 & 1.4 \\
\hline DDGS & --- & 12.7 & 25.4 \\
\hline Molasses (Black strap) & 3.2 & 3.2 & 3.2 \\
\hline Sheep Premix 2 & 1.3 & 1.3 & 1.3 \\
\hline \multicolumn{1}{|c|}{ Nutrient composition of treatment diets, g/100g DM } \\
\hline Dry Matter & 87.0 & 88.4 & 89.0 \\
\hline Crude Protein & 14.0 & 14.1 & 14.0 \\
\hline Ether Extract & 2.9 & 3.0 & 4.0 \\
\hline Neutral Detergent Fiber & 31.8 & 31.9 & 31.9 \\
\hline Acid Detergent Fiber & 14.0 & 15.1 & 15.0 \\
\hline Hemicellulose & 17.0 & 17.0 & 17.4 \\
\hline Ash & 4.0 & 4.1 & 4.6 \\
\hline Phosphorus & 0.39 & 0.40 & 0.42 \\
\hline Sulfur & 0.18 & 0.30 & 0.30 \\
\hline \multirow{2}{*yyy}{} & & \\
\hline
\end{tabular}

'All values are on dry matter basis except dry matter (unless otherwise indicated).

2 (\%) Ca 9.0, P 8.0, Salt 41.0, K 0.10, Mg 1.0; (ppm) Cu 1,750, Se 25.0, Zn 7,500, and (IU/kg) Vitamin A 308,644, Vitamin D 24,251 and Vitamin E 1,653.

Lambert-Powell Meat Laboratory (Auburn, $A L$ ) for slaughtering and subsequent carcass data collection. Carcass quality characteristics collected by trained personnel at 48-h postmortem (temperature <2 C, humidity near 100\%), included final hot and cold carcass weight, 12th rib fat thickness, body wall fat thickness, kidney and pelvic fat depots, and rib muscle area.

\section{Statistical Data Analysis}

The experiment was arranged as a randomized complete block, with pen as the experimental unit, and data were analyzed according to linear and quadratic orthogonal contrasts. Assumptions of normalitywere tested in the experiment using the UNIVARIATE procedure (SAS Inst. Inc., Cary, NC). The GLM procedure of SAS was used tostatistically analyze performance and carcass characteristicsin the experiment. The effects of treatment and block were included in the model statement for each experiment. In the experiment, least squares means were generated and separated using the PDIFF option of SAS for sig- 
Table 2. The effects of feeding different levels of dried distillers grains with solubles (DDGS) on performance of finishing lambs'.

\begin{tabular}{|c|c|c|c|c|c|c|}
\hline \multirow[t]{2}{*}{ Item } & \multicolumn{3}{|c|}{ Treatment diets, DDGS (\%) } & \multirow{2}{*}{ SEM } & \multicolumn{2}{|c|}{ P-value ${ }^{2}$} \\
\hline & $\begin{array}{c}0 \% \\
\text { (control) }\end{array}$ & $12.7 \%$ & $25.4 \%$ & & Linear & Quadratic \\
\hline \multicolumn{7}{|l|}{ Feed intake } \\
\hline Days on feed & 135 & 135 & 135 & - & - & - \\
\hline Dry matter intake $(\mathrm{kg})$ & 1.66 & 1.65 & 1.65 & 0.015 & 0.54 & 0.72 \\
\hline \multicolumn{7}{|l|}{ Body Weight } \\
\hline Average Daily Gain (kg/d) & $0.13^{a}$ & $0.12^{b}$ & $0.12^{b}$ & 0.003 & 0.05 & 0.34 \\
\hline Initial Body Weight (kg) & 45.40 & 45.47 & 47.50 & 0.90 & 0.20 & 0.44 \\
\hline Final Body Weight (kg) & 62.83 & 61.5 & 63.2 & 1.14 & 0.82 & 0.35 \\
\hline
\end{tabular}

'Eight lambs were assigned to each treatment ( $n=8 /$ dietary treatment).

${ }^{2} \mathrm{~B}$ ased on orthogonal contrasts for equally spaced tre atments.

$a, b$ Means without common superscript letters differ $(P<0.05)$.

Table 3. The effects of feeding different levels of dried distillers grains with solubles (DDGS) on carcass characteristics of lambs'.

\begin{tabular}{|c|c|c|c|c|c|c|}
\hline \multirow[t]{2}{*}{ Item } & \multicolumn{3}{|c|}{ Treatment Diets, DDGS (\%) } & \multirow[t]{2}{*}{ SEM } & \multicolumn{2}{|c|}{ P-value ${ }^{2}$} \\
\hline & $\begin{array}{c}0 \% \\
\text { (control) }\end{array}$ & $12.7 \%$ & $25.4 \%$ & & Linear & Quadratic \\
\hline \multicolumn{7}{|l|}{ Carcass Characteristics } \\
\hline Hot carcass weight $(\mathrm{kg})$ & 30.8 & 30.1 & 30.3 & 0.75 & 0.71 & 0.70 \\
\hline Cold carcass weight (kg) & 30.7 & 30.0 & 30.2 & 0.74 & 0.63 & 0.59 \\
\hline $12^{\text {th }}$ Rib fat thickness $(\mathrm{cm})$ & 0.91 & 1.61 & 0.85 & 0.34 & 0.90 & 0.18 \\
\hline Body wall fat thickness (cm) & 1.96 & 2.15 & 1.96 & 0.09 & 0.99 & 0.22 \\
\hline Kidney and pelvic fat weight $(\mathrm{kg})$ & 2.3 & 1.9 & 2.1 & 0.22 & 0.61 & 0.31 \\
\hline Rib Eye Area $\left(\mathrm{cm}^{2}\right)$ & 6.55 & 7.00 & 7.01 & 0.19 & 0.19 & 0.42 \\
\hline
\end{tabular}

${ }^{1}$ Eight lambs were assigned to each treatment $(n=8 /$ dietary treatment).

${ }^{2}$ Based on orthogonal contrasts for equally spaced treatments.

nificant main effects. The protected F-test was used to determine overall significance where $P$-values of $\leq 0.05$ were considered significant.

\section{Results}

\section{DDGS Chemical Composition}

In the current experiment, the $25.4 \%$ DDGS diet contained a minimal amount of SBM because the CP levels were met by DDGS and corn only. The fescue/bermuda grass mix hay used in the current study was comparable in protein content but lower in neutral detergent fiber and acid detergent fiber values in the literature (NRC, 2001). The different levels of DDGS inclusion resulted in different concentrations of $\mathrm{EE}$ in the experimental diets (Table 1). The calculated EE content of diets was 2.9, 3.0, and 4.0 for $0,12.7$, and $25.4 \%$ DDGS diets, respectively. As with any other by-product feed supplements, nutrient variability is one of the concerns with DDGS. The nutrient composition of
DDGS used in the current study was within the range of reported values. Dry Distillers grains with solubles ranged from 26.6 to $33.9 \%$ in $\mathrm{CP}$, from 10 to $15.9 \%$ in $\mathrm{EE}$, from 28.6 to $38.4 \%$ in NDF, from 2.45 to $9.25 \%$ in starch, from 0.77 to $1.06 \%$ in $P$, and 0.46 to $0.83 \%$ in $S$ (Janicek et al., 2008). Many factors influence nutrient contents of DDGS such as grain quality, milling process, fermentation process, drying temperatures and the amount of solubles blended back into the wet distiller grain with solubles at the time of drying (Kalscheur et al., 2005). The DDGS used in the current study was received from a single source and single production lot from the Dakota Gold Research Association (Poet Nutrition), Sioux Falls, SD.

\section{Lambs Performance and Carcass Characteristics}

Effect of different levels of DDGS on lamb performance and carcass quality characteristics are presented in Tables 2, 3. Lambs on all treatments had similar initial BW as designed (Table 2). Levels of DDGS has significant effect on final body 
weight and dry matter intake (Table 2). Moreover, hot and cold carcass weight, 12th rib fat thickness, body wall fat thickness, kidney and pelvic fat depot weights, and rib eye area were not affected by DDGS (Table 3). However, a decrease ( $P \leq 0.05)$ in average daily gain was recorded when 12.7 or $25.4 \%$ DDGS was included in the diets (Table 2).

\section{Discussion}

According to Archibeque et al. (2008) and Vander et al. (2009) feeding DDGS to ruminants would provide good source of energy compared to corn. Supplementation of DDGS in the diets of ruminants may be limited in their ability to improve dry matter digestibility, but it would provide additional protein sources to lambs consuming moderate-quality forage. Ham et al. (1994); Klopfenstein et al. (2008) and Vander et al. (2009) concluded that the energy value of WDGS was greater than the energy value of DDGS fed to cattle.

The present study is one of few studies provides information on the influence of feeding DDGS on finishing wether lambs carcass characteristics. It investigated the effects of the inclusion of up to $25.4 \%$ DDGS (DM basis) on DMI, ADG, and carcass characteristics including final BW, HCW, CCW, 12th rib fat, body wall fat, K\&P fat, and REA. Our hypothesis, that including up to $25.4 \%$ DDGS in the finishing diets of lambs will have no negative impact on DMI, ADG, and carcass characteristics, was supported by the results of the current experiment, except for ADG when 12.7 or $25.4 \%$ DDGS was included in diets.

\section{Feed Intake}

There were no differences in feed intake between the experimental diets. The mean DMI were $1.66,1.65$ and $1.66 \mathrm{~kg} / \mathrm{d}$ for $0,12.7$, or $25.4 \%$ DDGS, respectively. The lack of differences in DMI among treatments may be due to similarity of NDF concentrations in the experimental diets The results of the present study agree with previous literature (Powers et al., 1995; Liu et al., 2000; Hippen et al., 2003, Huls et al., 2006; Kleinschmit et al., 2006 ; Van Emon et al., 2008) that including DDGS in finishing diets of lambs have not increase DMI. Kleinschmit et al. (2006) found that included $20 \%$ of DDGS in dairy cattle diet did not affect the feed intake. Liu et al. (2000) also compared DDGS versus a blend of other protein sources on lactating cows. They found that DDGS had no effect on dry matter intake. However, results from the present study disagree with the findings of Trenkle (2004); Buckner et al. (2007); Archibeque et al. (2008) and Schaver et al. (2008) that including DDGS in finishing diets of lambs have increased DMI. Archibeque et al. (2008) evaluated the potential of DDGS as a supplement for finishing lambs consuming moderate-quality forages. They noticed a modest increase in average DMI in lambs fed DDGS. Schaver et al. (2008) also evaluated the effect of feeding increasing levels of DDGS in lamb-finishing rations on lamb performance and carcass characteristics. They observed that DMI increased in a linear manner as level of DDGS inclusion increased. Moreover, Trenkle (2004) evaluated the influence of DDGS on finishing Holstein steers. They detected an increase in DMl in growing calves that was fed up to $40 \%$ DDGS (DM basis; $90 \%$ concentrate diets). Likewise, Buckner et al. (2007) compared a modified dry byproduct to dry distillers grains with solubles in growing calf diets by replacing a portion of bromegrass hay and alfalfa haylage with 15 or $30 \%$ DDGS. They recorded an increase in DMI in steer calves fed 30\% DDGS diets compared with steers consuming $15 \%$ DDGS. Leupp et al. (2009) also investigated the effects of increasing levels of DDGS in diets containing $70 \%$ concentrate offered to growing steers on DMl, rate and site of digestion, ruminal fermentation, duodenal protein flow, and microbial efficiency. They noticed that DMI responded quadratically with greatest intakes at 15\% DDGS and least at 60\% DDGS.

\section{Body Weight}

Feeding DDGS can increase ADG in growing cattle consuming both low-quality and high-quality forages (Loyet al., 2007; Morris et al., 2005), but the reason for increased gain is not fully elucidated. Dried distillers grains contain 15 to $20 \%$ UIP and 8 to $12 \%$ fat (MacDonald et al., 2007). Thus, it is possible that UIP and additional energy is responsible for the additional gain. There were no differences in BW gain between treatments. The mean ADG and final $B W$ were $0.13 \mathrm{~kg} / \mathrm{d}$ and $62.83 \mathrm{~kg}$ for 0\% DDGS, $0.12 \mathrm{~kg} / \mathrm{d}$ and $61.6 \mathrm{~kg}$ for $12.7 \%$ DDGS, and 0.12 $\mathrm{kg} / \mathrm{d}$ and $63.2 \mathrm{~kg}$ for $25.4 \%$ DDGS, respectively (Table 2). In contrast to the present study, Klopfenstein et al. (2008) noticed quadratic response in ADG and a cubic response in G:F as level of DDGS in the diet increased from 0 to $40 \%$. Similarly, previous research (MacDonald et al., 2007; Martin et al., 2007; Depenbusch et al., 2008; Schaver et al., 2008; Van Emon et al. (2008); and McEachern et al., 2009) showed that including DDGS in finishing diets of lambs have not influenced ADG. Also, Depenbusch et al. (2008) compared growth performance and carcass characteristics in yearling heifers fed diets based on steam-flaked corn with or without DDGS. In contrast with the results of the current study, they noticed that ADG and gain efficiencies were not increased when DDGS included in the diets. Furthermore, Martin et al. (2007) investigated the influence of DDGS as an energy source on growth and reproduction of heifers. They reported that ADG was not affected by DDGS supplementation. Moreover, Van Emon et al. (2008) investigated the influence of feeding as much as $50 \%$ DDGS on lamb carcass characteristics. Contrary to the present study, they found that supplementation of grazing lambs with DDGS increased ADG.

\section{Carcass Characteristics}

There were no significant differences in carcass characteristics between treatments. The mean HCW, CCW, 12th rib fat, body wall fat, kidney and pelvic fat, and REA were $30.8 \mathrm{~kg}$, $30.7 \mathrm{~kg}, 0.91 \mathrm{~cm}, 1.96 \mathrm{~cm}, 2.3 \mathrm{~kg}$, and $6.55 \mathrm{~cm} 2$ for $0 \%$ DDGS, $30.1 \mathrm{~kg}, 30.0, \mathrm{~kg} 1.61 \mathrm{~cm}, 2.15 \mathrm{~cm}, 1.9 \mathrm{~kg}$, and $7.0 \mathrm{~cm}$ for $12.7 \%$ DDGS, and $30.3 \mathrm{~kg}, 30.2 \mathrm{~kg}, 0.85 \mathrm{~cm}, 1.96 \mathrm{~cm}, 2.1 \mathrm{~kg}$, and $7.01 \mathrm{~cm}$ for $25.4 \%$.

The results of the present study agree with previous research (Huls et al., 2006; Depenbusch et al., 2008; Schaver et al., 2008; Depenbusch et al., 2009; Neville et al., 2010; Whitney 
and Braden, 2010b) showed no influence of DDGS on carcass characteristics when DDGS was included in lambs finishing diets. Huls et al. (2006) investigated efficacy of DDGS as a replacement for CSM and a portion of the corn in a finishing lamb diet and reported that lamb BFT decreased, but other carcass characteristics remained similar when DDGS replaced SBM and a portion of the corn in 90-percent concentrate diets. Schaver et al. (2008) also reported no effect on HCW, BFT, and REA when $0,20,40$, and $60 \%$ DDGS was included in lambs diets. Whitney and Braden (2010b) also investigated the effects of CSM with DDGS on carcass characteristics, meat fatty acid profiles, and sensory panel traits, and reported that partially or totally substituting DDGS for CSM in lamb-finishing diets is acceptable and may enhance sensory traits. The authors concluded that the inclusion of DDG in lamb finishing diets has shown no negative effect on carcass characteristics, thus it could serve as a plausible substitute for CSM in lamb-finishing diets. Likewise, Neville et al. (2010) evaluated the influence of thiamine supplementation on feedlot performance and carcass quality and also noticed that increasing DDGS in diets up to 60 percent did not affect lamb carcass characteristics, except for increased flank streaking and USDA quality grade. Similar results have been reported in cattle (Depenbusch et al., 2008; Depenbusch et al., 2009). Depenbusch et al. (2008) investigated the influence of corn distillers grains with solubles on growth performance and carcass characteristics of finishing feedlot heifers and reported that carcass weight, dress yield, LM area, KPH fat, and $12^{\text {th }}$-rib fat were not significantly different among treatments.

\section{Conclusion}

The growth in the biofuel industries and subsequent development of dry-milling production facilities resulted in volatile futures markets and increased grain costs traditionally used in feedlot diets. Dry Distillers grains with solubles like corn-based ethanol byproducts are an excellent protein and energy source, but are high in fiber which can negatively impact DDGS digestibility. Literature suggested that feeding DDGS to ruminants would provide similar or more amounts of energy compared to corn, and DDGS supplement. The results of this study demonstrated that supplementation of lambs-finishing diet with DDGS did not negatively affect DMI or carcass characteristics. Overall, the current research confirms previous work demonstrating that DDGS can be included in lamb finishing rations at concentrations up to $25 \%$ of dietary DM. Further research is needed to examine the efficacy of including DDGS in meat lambs diets.

\section{Acknowledgments}

This manuscript is based on research funded by the Alabama Agricultural Land Grant-Alliance (AALGA) and the Dakota Gold Research Association, Sioux Falls, SD. We thank the staff at the AAMU Winfred Thomas Agricultural Research Station and the Department of Food \& Animal Sciences for their support throughout the study. Also, we wish to thank Dr. Jorge Vizcarra for assistance with statistical analyses, Auburn University Lambert-Powell meat Laboratory for assistance with carcass evalua- tion, and Dr. James Shuford for his comments on the manuscript.

\section{References}

Archibeque SL, HC Freetly, and CL Ferrell (2008) Feeding distillers grains supplements to improve amino acid nutriture of lambs consuming moderate-quality forages. J. Anim. Sci. 86: 691-701.

Buckner CD, TJ Klopfenstein, GE Erickson, KJ Vander Pol, KK Karges, and ML Gibson (2007) Comparing a modified dry by-product to dry distillers grains with solubles in growing calf diets. In: Leupp et al. (2009) Effects of increasing level of corn distillers dried grains with solubles on intake, digestion, and ruminal fermentation in steers fed seventy percent concentrate diets. J. Anim. Sci. 87: 2906-2912.

Depenbusch BE, ER Loe, MJ Quinn, ME Corrigan, ML Gibson, KK Karges, and JS Drouillard (2008) Corn distillers grains with solubles derived from a traditional or partial fractionation process: Growth performance and carcass characteristics of finishing feedlot heifers. J. Anim. Sci. 86: 2338-2343.

Engel CL, HH Patterson, and GA Perry (2008) Effect of dried corn distillers grains plus solubles compared with soybean hulls, in late gestation heifer diets, on animal and reproductive performance. J. Anim. Sci. 86: 1697-1708.

FASS (1999) Guide for the Care and Use of Agricultural Animals in Agricultural Research and Teaching. 1 st rev. ed. Fed. Animal Science Society, Savoy, IL.

Gunn PJ, MK Neary, RP Lemenager, and SL Lake (2010) Effects of crude glycerin on performanceand carcass characteristics of finishing wether lambs. J. Anim. Sci. 88: 1771-1776.

Ham GA, RA Stock, TJ Klopfenstein, EM Larson, DH Shain, and RP Huffman (1994) Wet corn distillers byproducts compared with dried corn distillers grains with solubles as a source of protein and energy for ruminants. J. Anim. Sci. 72: 3246-3257.

Hippen AR, KN Linke, KF Kalscheur, DJ Schingoethe, and AD Garcia (2003) Increased concentrations of wet distillers in dairy cow diets. J. Dairy Sci. 86 (Suppl. 1): 340. (Abstr.).

Huls TJ, AJ Bartosh, JA Daniel, RD Zelinsky, J Held, and AE Wertz-Lutz (2006) Efficacy of dried distiller's grains with solubles as a replacement for soybean meal and a portion of the corn in a finishing lamb diet. Sheep and Goat Res. J. 21 : 30-34.

Jacob ME, JT Fox, SK Narayanan, JS Drouillard, DG Renter, and TG Nagaraja (2008) Effects of feeding wet corn distillers grains with solubles with or without monensin and tylosin on the prevalence and antimicrobial susceptibilities of fecal foodborne pathogenic and commensal bacteria in feedlot cattle. J. Anim. Sci. 86: 1182-1190.

Janicek BN, PJ Kononoff, AM Gehman, PH Doane (2008) The Effect of Feeding Dried Distillers Grains Plus Solubles on Milk Production and Excretion of Urinary Purine Derivatives. J. Dairy Sci. 91 : 35443553.

Kalscheur KF, P Exbrayat, and AD Garcia (2005) Nutrient digestibility and excretion of dairy heifers Fed diets with increasing concentrations of corn distillers grains. J. Anim. Sci. 83 (Suppl. 1): 255.

Kleinschmit DH, DJ Schingoethe, KF Kalscheur, and AR Hippen (2006) Evaluation of various sources of corn dried distillers grains plus solubles for lactating dairy cattle. J. Dairy Sci. 89: 4784-4794.

Klopfenstein TJ (2001) Distillers grains for beef cattle. In: Leupp et al. (2009) Effects of increasing level of corn distillers dried grains with solubles on intake, digestion, and ruminal fermentation in steers fed seventy percent concentrate diets. J. Anim. Sci. 87: 2906-2912.

Klopfenstein TJ, GE Erickson, and VR Bremer (2008) Board-Invited Review: Use of distillers by-products in the beef cattle feeding industry. J. Anim. Sci. 86: 1223-1231.

Koger TJ, DM Wulf, AD Weaver, CL Wright, KE Tjardes, KS Mateo, 
TE Engle, RJ Maddock, and AJ Smart (2010) Influence of feeding various quantities of wet and dry distillers grains to finishing steers on carcass characteristics, meat quality, retail-case life of ground beef, and fatty acid profile of longissimus muscle. J. Anim. Sci. 88: 3399-3408.

Leupp JL, GP Lardy, KK Karges, and JS Caton (2009) Effects of increasing level of corn distillers dried grains with solubles on intake, digestion, and ruminal fermentation in steers fed seventy percent concentrate diets. J. Anim. Sci. 87: 2906-2912.

Liu C, DJ Schingoethe, and GA Stegeman (2000) Corn distillers grains versus a blend of protein supplements with or without ruminally protected amino acids for lactating cows. J. Dairy Sci. 83: 2075-2084.

Loy TW, JC MacDonald, TJ Klopfenstein, and GE Erickson (2007) Effect of distillers grains or corn supplementation frequency on forage intake and digestibility. J. Anim. Sci. 85: 2625-2630.

MacDonald JC, TJ Klopfenstein,GE Erickson, and WA Griffin (2007) Effects of dried distillers grains and equivalent undegradable intake protein or ether extract on performance and forage intake of heifers grazing smooth bromegrass pastures. J. Anim. Sci. 85: 2614-2624.

McEachern JK, TR Whitney, CB Scott, CJ Lupton, and MW Salisbury (2009) Substituting distillers dried grains for cottonseed meal in lamb-finishing diets: growth, wool characteristics, and serum NEFA, urea N, and IGF-1 concentrations. Sheep Goat Res. J. 23: 15-19.

Martin JL, AS Cupp, RJ Rasby, ZC Hall, and RN Funston (2007) Utilization of dried distillers grains for developing beef heifers. J. Anim. Sci. 85: 2298-2303.

Morris SE, TJ Klopfenstein, DC Adams, GE Erickson, and KJ Vander Pol (2005) The effects of dried distillers grains on heifers consuming low or high-quality forage. Nebraska Beef Cattle Report. MP 83-A:1820. In: MacDonald et al. (2007) Effects of dried distillers grains and equivalent undegradable intake protein or ether extract on performance and forage intake of heifers grazing smooth bromegrass pastures. J. Anim. Sci. 85: 2614-2624.

Neville BW, CS Schaver, K Karges, ML Gibson, MM Thompson, LA Kirschten, NW Dyer, PT Berg, and GP Lardy (2010) Effect of thiamine concentration on animal health, feedlot performance, carcass characteristics, and ruminal hydrogen sulfide concentrations in lambs fed diets based on $60 \%$ distillers dried grains plus soluble. J. Anim. Sci. 88: 2444-2455.

NRC (2000) Nutrient Requirements of Beef Cattle. 7th rev. ed. Natl. Acad. Press, Washington, DC.

NRC (2001) Nutrient Requirements of Dairy Cattle. National Academy Press, Washington, DC.

NRC (2007) Nutrient Requirements of Small Ruminants: Sheep, Goats, Cervids, and New World Camelids, National Academy Press, Washington, DC.

Powers WJ, HH Van Horn, B Harris, and CJ Wilcox (1995) Effects of variable sources of distillers dried grains plus solubles on milk yield and composition. J. Dairy Sci. 78: 388-396.

Renewable Fuels Association (2009) Ethanol industry statistics. Renewable Fuels Association. In: Koger et al. (2010) Influence of feeding various quantities of wet and dry distillers grains to finishing steers on carcass characteristics, meat quality, retail-case life of ground beef, and fatty acid profile of longissimus muscle. J. Anim. Sci. 88: 3399-3408.

SAS (2008) Users guide. SAS Inst. Inc., Gary, NC.

Schaver CS, MM Stamm, TD Maddock, and PB Berg (2008) Feeding $60 \%$ of lamb finishing rations as dried distillers grains with solubles results in acceptable performance and carcass quality. Sheep Goat Res. J. 23: 15-19.

Schingoethe DJ, KF Kalscheur, AR Hippen, and AD Garcia (2009) The use of distillers products in dairy cattle diets. J. Dairy Sci. 92: 58025813.

Schmit TM, RN Boisvert, D Enahoro, and LE Chase (2009) Bottom of Form Optimal dairy farm adjustments to increased utilization of corn distillers dried grains with soluble. J. Dairy Sci. 92: 1267-1281.

Spiehs MJ, MH Whitney, and GC Shurson (2002) Nutrient database for distiller's dried grains with solubles produced from new ethanol plants in Minnesota and South Dakota. Anim. Sci. 80: 2639-2645.

Stock RA, JM Lewis, TJ Klopfenstein, and CT Milton (2000) Review of new information on the use of wet and dry milling feed by-products in feedlot diets. Available inhttp://www.asas.org/JAS/symposia/ proceedings/0924.pdf Accessed January 3, 2011.

Trenkle A (2004) Evaluation of wet and dry distillers grains with solubles for finishing Holstein steers. In: Leupp et al. (2009) Effects of increasing level of corn distillers dried grains with solubles on intake, digestion, and ruminal fermentation in steers fed seventy percent concentrate diets. J. Anim. Sci. 87: 2906-2912.

Van Emon ML, AF Musselman, PJ Gunn, MK Neary, RP Lemenager, and SL Lake (2008) Effects of added protein and dietary fat on lamb performance and carcass characteristics when fed differing levels of dried distiller's grains with solubles. J. Anim. Sci. 86 (E-Suppl. 2): 497. (Abstr.).

Vander Pol KJ, MK Luebbe, GI Crawford, GE Erickson, and TJ Klopfenstein (2009) Performance and digestibility characteristics of finishing diets containing distillers grains, composites of corn processing coproducts, or supplemental corn oil. J. Anim. Sci. 87: 639-652.

Whitney TR, and CJ Lupton (2010a) Evaluating percentage of roughage in lamb finishing diets containing $40 \%$ dried distillers grains: Growth, serum urea nitrogen, nonesterified fatty acids, and insulin growth factor- 1 concentrations and wool, carcass, and fatty acid characteristics. J. Anim. Sci. 88: 3030-3040.

Whitney TR, and KW Braden (2010b) Substituting Corn Dried Distillers Grains for Cottonseed Meal in lamb Finishing Diets: Carcass Characteristics, Meat Fatty Acid Profiles, and Sensory Panel Traits. Sheep and Goat Res J. 25: 50-56. 